\title{
Strategi Branding Sirup Kayu Manis sebagai Minuman Khas Desa Renah Alai Kecamatan Jangkat Kabupaten Merangin
}

\author{
Parmadi $^{1}$, Dwi Hastuti ${ }^{2 *}$, Erfit ${ }^{3}$, Rahma Nurjanah ${ }^{4}$, Selamet Rahmadi ${ }^{5}$ \\ 1,2,3,4,5) Prodi Ekonomi Pembangunan Fakultas Ekonomi dan Bisnis Universitas Jambi
}

\begin{abstract}
Technological advancements have kept pace with industrial advancements, and we are presently in the 5.0 industrial revolution. However, during the Covid-19 pandemic, the level of income and welfare did not follow the speed of technological advancement. This is due to the product's low demand, which stems from the fact that it is less well-known and less compelling without package labels. This is a challenge for the government, the community, and the PPM FEB Jambi University community service team. This activity is in line with the partner village agreement between EP FEB UNJA and Renah Alai Village. The team consistently performs community service in the $3^{\text {rd }}$ year in 2021. Furthermore, the pandemic affects people's income, and lowers people's purchasing power. As a result, strategies to boost people's income can be done through cinammon business opportunities and branding strategies for promoting the products. The service methods used in achieving PPM goals include: 1) Community-based development, 2) Persuasive, 3) Educational, 4) Participatory, and 5) Normative. Explanation, discussion, and practice is majorly used for this community service activity. It was carried out in particular to address issues relating to the production and promotion of cinnamon syrup products. Students participated in the PPM program approximately for 8 months. With the increased promotion of the cinammon branding strategy, it is hoped that tourism would flourish and it became the specialty beverage of Renah Alai Village, as well as the economy and technology in Renah Alai Village to create sustainable tourism.
\end{abstract}

Keywords: branding strategy, income, welfare

\begin{abstract}
Abstrak
Perkembangan teknologi terus meningkat seiring dengan perkembangan industri hingga sekarang sudah berada pada revolusi industri 5.0. Akan tetapi, tingkat pendapatan ekonomi dan kesejahteraan tidak mengikuti pergerakan teknologi ini di tengah pandemi Covid-19. Hal ini disebabkan oleh rendahnya permintaan produk karena produk kurang terkenal dan kurang meyakinkan tanpa label kemasan. Permasalahan ini menjadi tantangan bagi pemerintah, masyarakat dan tim pengabdian PPM FEB Universitas. Kegiatan ini sejalan dengan surat perjanjian desa mitra antara Prodi Ekonomi Pembangunan dan Desa Renah Alai Nomor 107/UN21.5.3/KS/2020 dan Nomor 141.1/026/KDRA/2020. Tim secara konsisten melakukan pengabdian pada tahun ke-3 pada periode 2021. Selain itu, pandemi menurunkan pendapatan masyarakat sehingga daya beli juga menurun. Untuk itu, strategi untuk meningkatkan pendapatan masyarakat dapat melalui peluang bisnis kayu manis dan strategi branding untuk pemasaran produknya. Metode pengabdian yang digunakan dalam pencapaian tujuan PPM antara lain: 1) Pengembangan berbasis komunitas, 2) Persuasif, 3) Edukatif, 4) Partisipatif, dan 5) Normatif. Sebagian besar kegiatan pengabdian menggunakan metode penjelasan, diskusi, dan praktik. Secara khusus, kegiatan ini dilakukan untuk menjawab persoalan terkait dengan pengembangan promosi produk sirup kayu manis. Selama program PPM, mahasiswa ikut terlibat selama \pm 8 bulan. Dengan adanya peningkatan promosi strategi branding kayu manis,
\end{abstract}

\footnotetext{
* Penulis korespondensi

Email: dwihastuti@unja.ac.id
} 
diharapkan dapat mengembangkan pariwisata dari sisi minuman khas Desa Renah Alai, ekonomi, dan teknologi dalam menciptakan pariwisata yang berkelanjutan.

Kata kunci: strategi branding, pendapatan, kesejahteraan

\section{Pendahuluan}

Pergerakan teknologi atau sistem informasi yang terkait dengan pemasaran elektronik dikenal dengan istilah e-commerce. Hal ini sangat berkaitan dengan kemudahan pelaku UKM untuk berinovasi dan melakukan produksi serta penjualan produk. Selain itu, rendahnya kesadaran Usaha Kecil Menengah (UKM) akan hal ini tergambar pada masih rendahnya penggunaan label pada kemasan produk (Herydiansyah, 1970). Salah satu upaya meningkatkan kesejahteraan penduduk desa adalah dengan pengembangan produk unggulan daerah melalui pemasaran online dengan sebuah kemasan dan merek dalam sebuah produk (Yudanto, dkk., 2019). Dengan kata lain, dengan adanya label suatu produk akan memberikan kesan yang baik terhadap suatu produk dan kemudian meningkatkan keuntungan atau profit yang diperoleh. Secara tidak langsung peningkatan pendapatan akan berpengaruh terhadap peningkatan kesejahteraan (Hendrayani and Manihuruk, 2020).

Menurut Kastaman \& Thoriq (2021), dengan adanya prioritas produk agroindustri maka strategi pengembangannya bagi petani terdiri dari :

1) Branding dan promosi produk

2) Peningkatan kualitas produk melalui penerapan Good Manufacturing Practice (GMP) dan Cleanser Production

3) Pengembangan dan inovasi produk

4) Peningkatan kualitas sumber daya manusia

5) Peningkatan kesejahteraan petani

6) Bibit unggul yang mampu adaptif terhadap lingkungan

7) Peningkatan harga jual buah

Strategi pengembangan itu menunjukkan bahwa branding sangat produk untuk pengembangan produk (Kastaman \& Thoriq, 2021; Susanto \& Nurcahyanto, 2018; Yudanto, dkk., 2019). Hal ini sejalan dengan pernyataan bahwa desain produk merupakan faktor yang sangat penting untuk menguatkan branding UMKM (Hendrayani \& Manihuruk, 2020).

Menurut Yasa, dkk., (2020), strategi pengembangan produk seringkali menitikberatkan pada pengembangan diversifikasi produk, diferensiasi, branding produk, dan maksimalisasi kerjasama dalam meningkatkan kualitas. Kata branding menjadi sangat penting dalam penyampaian pesan dari produsen kepada konsumen (Susanto \& Nurcahyanto, 2018). Untuk mendesain produk harus dilakukan perancangan desain kemasan yang meningkatkan brand awareness dan keunggulan suatu produk (Hendrayani \& Manihuruk, 2020). Desain suatu produk sangat berkaitan dengan bentuk, struktur, material, warna, citra, tipologi, dan elemen-elemen desain dengan informasi produk yang dipasarkan (Hendrayani \& Manihuruk, 2020). Tujuan desain produk ini menurut, yaitu agar kemasan menjadi lebih menarik sehingga memiliki fungsi yang maksimal berlaku untuk membungkus, melindungi, mengirim, mengeluarkan, menyimpan, mengidentifikasi, dan membedakan dengan produk lainnya.

Di tengah pandemi Covid-19, meningkatkan nilai ekonomi UMKM dapat melalui digital marketing (Sholawati, dkk., 2020). Saat ini, sebagian besar masyarakat meningkatkan penjualan menggunakan media sosial dan delivery sehingga tidak memerlukan sewa tempat. 
Selanjutnya untuk pengembangan produknya menitikberatkan pada lima poin yaitu identifikasi masalah, pentingnya branding dan legalitas usaha, pengemasan produk, katalog dan iklan yang menarik.(Sholawati, dkk., 2020). Motivasi peningkatan usaha terlihat dari banyaknnya produk banding yang bermunculan (Nurmiyati, dkk., 2019). Dengan demikian pemasaran sangat berkaitan dengan desain produk untuk pengemasan dan branding hingga strategi proses pemasaran (Kristianto, 2020). Peningkatan produksi produk yang tinggi terlihat dari potensi sumber daya alam yang dimiliki sebagai bahan input pembuatannya.

Salah satu desa yang memiliki potensi sumber daya alam (SDA) di Kecamatan Jangkat Kabupaten Merangin adalah Desa Renah Alai. Desa ini dijuluki sentra produksi bahan pertanian sehingga menjadikan aktivitas ekonomi di desa ini tinggi (Parmadi, dkk., 2019). Selanjutnya, berdasarkan pelatihan pengabdian di Tahun 2020 tentang potensi Desa Renah Alai yang menunjukkan bahwa kayu manis dapat menjadi peluang usaha bagi masyarakat desa sebagai minuman khas atau oleh-oleh yang berasal dari desa ini. Pengembangan produk kayu manis ini juga merupakan strategi dalam meningkatkan potensi wisata. Salah satunya adalah dengan menyediakan makanan olahan yang berasal dari produk potensial dengan melakukan diversifikasi produk. Kegiatan ini juga akan memberikan dampak pada perubahan aktivitas masyarakatnya. Hal ini juga dikemukakan oleh Kurniawan (2020) yang menyatakan bahwa tantangan teknologi digitalisasi produk berdasarkan potensi desa yang dimiliki dengan potensi yang besar dalam mengembangkan agrowisata (Kurniawan, 2020; Rai, dkk., 2012).
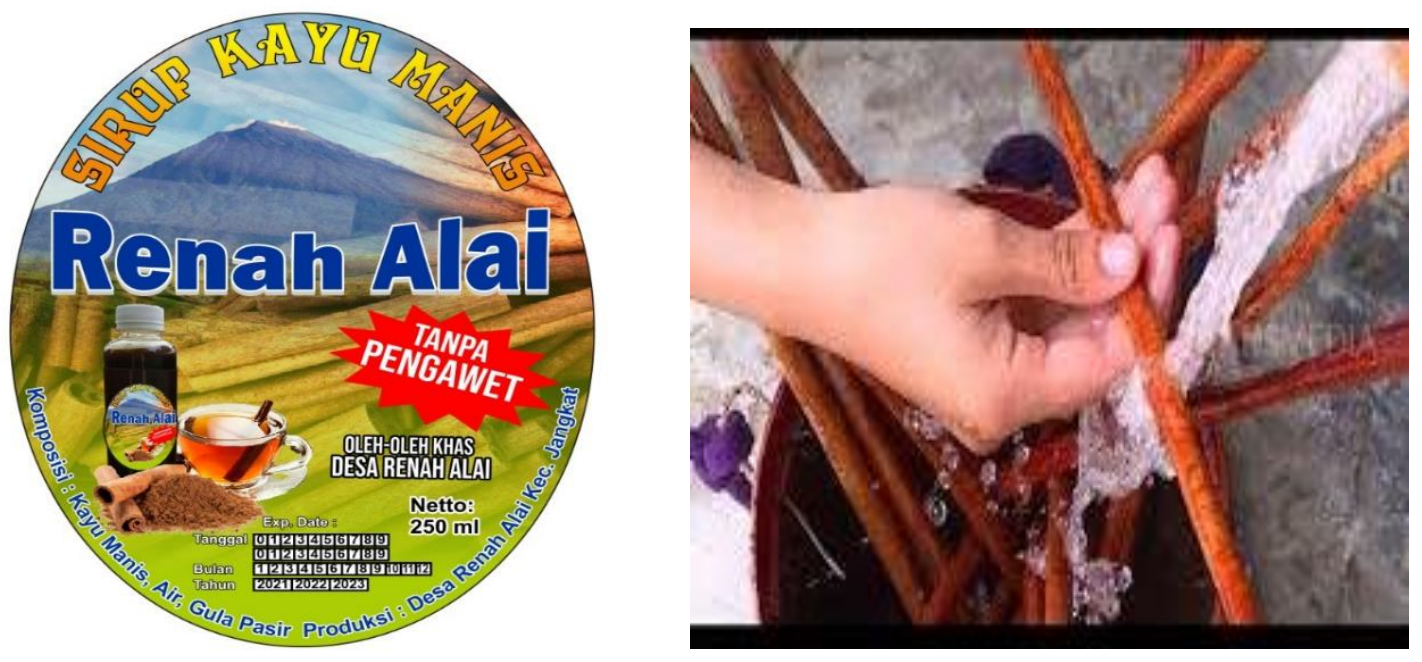

Gambar 1. Contoh Branding Sirup Kayu Manis

Potensi sumber daya alam sebagai warisan leluhur serta produk-produk yang memiliki potensi tinggi menjadi salah satu topik utama dalam pengabdian. Berdasarkan pemaparan sebelumnya mengenai tantangan dan peluang, maka tim pengabdian tertarik untuk melakukan pengabdian berjudul "Strategi Branding Sirup Kayu Manis sebagai Minuman Khas Desa Renah Alai Kecamatan Jangkat Kabupaten Merangin”.

\section{Rumusan masalah}

Peningkatan kesejahteraan merupakan tujuan pembangunan ekonomi yang berkelanjutan, misalnya dengan mengembangkan produk unggulan terkait dengan strategi branding dan pemasaran online. Selain itu, dengan peningkatan pengetahuan atau aspek 
kognitif, maka akan mendorong kesadaran masyarakat akan pentingnya sebuah merek pada sebuah produk (Yudanto, dkk., 2019). Saat ini banyak sekali produk dengan berbagai variasi bentuk, serta kemasan yang menarik dengan tujuan untuk meningkatkan penjualan dan story telling terkait dengan sejarah produk tersebut. Dengan adanya pemberdayaan branding di Desa Renah Alai diharapkan dapat meningkatkan nilai tambah suatu produk yang pada akhirnya meningkatkan kesejahteraan petani dan masyarakat sekitarnya (Hendrayani and Manihuruk, 2020).

Branding dalam kegiatan pemasaran menjadi sangat penting dalam menyampaikan pesan dari produsen kepada konsumen. Tantangan sampai saat ini, usaha kecil menengah (UKM) yang kurang disadari akan pentingya merek atau brending pada suatu produk (Susanto and Nurcahyanto, 2018). Seperti halnya, yang terjadi di Desa Renah Alai dimana setelah dilakukan cara pengelolaan kayu manis menjadi sirup kayu manis di tahun 2020 belum terdapat perkembangan yang signifikan terkait dengan permintaan dan penjualan produk. Oleh karena itu, pada tahun 2020 dilanjutkan dengan strategi branding sirup kayu manis yang diharapkan dapat menjadi minuman khas Desa Renah Alai, dan meningkatkan brand awareness serta produk unggulan di desa ini.

Perkembangan teknologi yang semakin canggih mempercepat kemajuan pariwisata, (Mertayasa \& Yambese, 2017; Rusdi, 2019). Melalui penyebaran informasi yang cepat di era digitalisasi terkait dangan pentingnya branding akan mempengaruhi peningkatan permintaan terhadap suatu potensi produk yang dihasilkan suatu daerah di tengah situasi saat ini. Hal ini sejalan peryataan Siswanto (2009) yang menyatakan bahwa peningkatan keahlian teknologi informasi yang memiliki prospek pertumbuhan ketika terjadi krisis. Berdasarkan justifikasi anggaran pengabdian dalam penelitian tahun 2021 yang telah berjalan 3 (tiga) tahun diharapkan pengabdian ini dapat optimal dengan kerja sama masyarakat Desa Renah Alai dan tim pengabdian. Secara khusus untuk menjawab persoalan terkait dengan strategi branding sirup kayu manis sebagi minuman khas Desa Renah Alai selama program PPM dengan melibatkan mahasiswa magang dan tim dari Dinas Koperasi, UMKM dan Perindustrian dan pakar IT yang membantu penyelenggaraan ini serta tim dari BAPPEDA Kabupaten Merangin.

\section{Solusi permasalahan mitra}

Pengembangan produk olahan sirup kayu manis yang belum optimal disebabkan karena strategi branding belum maksimal. Potensi dan wisata menjadi tantangan di era ini karena banyaknya informasi akan menciptakan permintaan dan menjawab permasalahan masyarakat dalam penyaluran dan penjualan produk. Berbagai analisis yang telah dikemukakan oleh bebrapa ahli menyebutkan bahwa proses branding sangat penting bagi dalam peningkatan promosi suatu produk yang akan mempengaruhi pertumbuhan ekonomi dan kesejahteraan masyarakat.

Proses penerapan website sebagai solusi bagi permasalahan desa mitra dapat menjadi acuan dasar tim mengajukan PPM dengan melibatkan mahasiswa dan dinas terkait. Target yang ingin dicapai pada kegiatan pelatihan melalui pengabdian kepada masyarakat (PPM) dengan pemberdayan masyarakat terkait pemanfaatan sirup kayu manis yang dihasilkan oleh masing-masing rumah tangga di Desa Renah Alai Kecamatan Jangkat Kabupaten Merangin adalah sebagai berikut:

1. Mahasiswa yang terlibat ada 3 orang mahsiswa pada bulan Juli 2021. Mahasiswa ini dapat membantu peserta pengabdian kepada masyarakat program PPM FEB UNJA. Selain itu dinas UMKM Kbupaten Merangin yang akan membentu memberikan penyuluhan terkait tentang branding 
2. Pelaksanaan PPM sebagai bentuk Tridarama Perguruan Tinggi Universitas Jambi dan membantu mengatasi permasalahan yang dimiliki oleh kelompok masyarakat di Desa Renah Alai Kecamatan Jangkat Kabupaten Merangin

Luaran pengabdian PPM yang diharapkan pada tahun ke-3 pada desa binaan Prodi Ekonomi pembangunan No.141.1/026/KDRA/2020 dan No: 107/UN21.5.3/KS/2020 tentang pengembangan desa mitra dapat meningkatkan nilai suatu produk kayu manis. Kegiatan penerapan website sebagai wadah pengembangan potensi Agrowisata Desa Renah Alai yang diharapkan dapat meningkatkan pertumbuhan ekonomi dan kesejahteraan masyarakat. Strategi promosi dengan menawarkan potensi pariwisata, dan produk 57 tati akan memberikan peluang bagi masyarakat di Desa Renah Alai Kecamatan Jangkat Kabupaten Merangin melalui kegiatan Pengabdian Kepada Masyarakat.

\section{Metode Pengabdian}

Metode pelaksanaan pengabdian skema Program PPM UNJA Tahun 2021 terdiri dari beberapa tahapan yaitu: 1) Survei lokasi pengabdian, 2) Negosiasi Mitra, 3) Penandatanganan mitra, 4) Pengurusan surat izin lapangan dari LPPM dan Fakultas, dan 5) Monitoring serta evaluasi kegiatan.

Adapun tahapan-tahapan pengabdian kepada masyarakat skema di Desa Renah Alai Kecamatan Jangkat Kabupaten Merangin yang akan dilaksanakan di tahun 2021 adalah sebagai berikut:

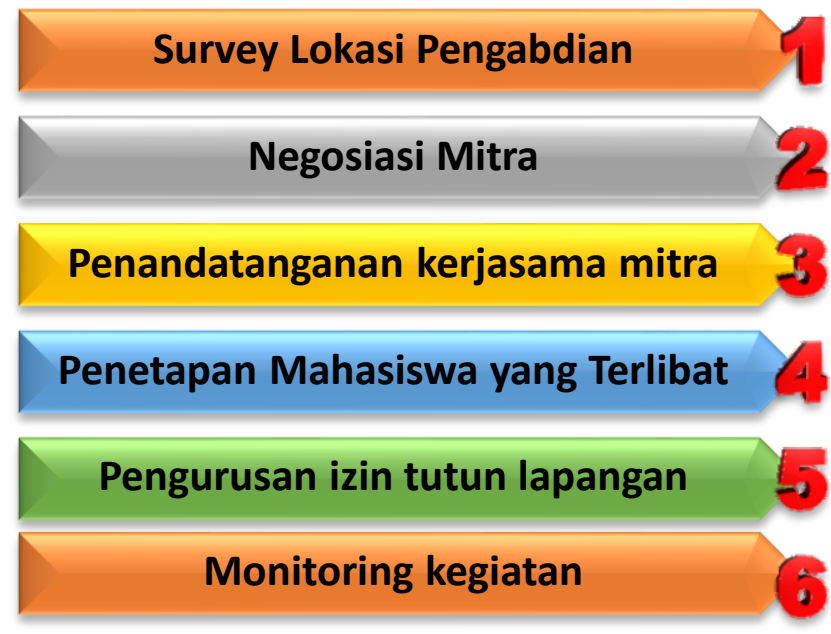

Gambar 2. Tahapan Pelaksanaan Kegiatan Pengabdian (PPM)

\section{Pelaksanaan pengabdian}

Tahap perencanaan dapat dikatakan sebagai tahap awal atau tahap permulaan yang wajib dilakukan dalam merumuskan agenda pelaksanaan pengabdian kepada masyarakat (PPM) pada semester ganjil Tahun 2020/2021. Berdasarkan rapat yang dilaksanakan oleh Fakultas Ekonomi dan Bisnis disepakati bahwa dilakukan pengabdian secara berkelompok dan difokuskan di daerah Merangin tepatnya di Desa Renah Alai Kecamatan Jangkat Kabupaten Merangin. Selain itu, Bentuk konsistensi dari MoU antara prodi ekonomi pembangunan dan Desa Renah Alai dilanjutkan di Tahun 2021 dengan PPM skema. Adapun metode pendekatan dalam pelaksanaan PPM adalah: 


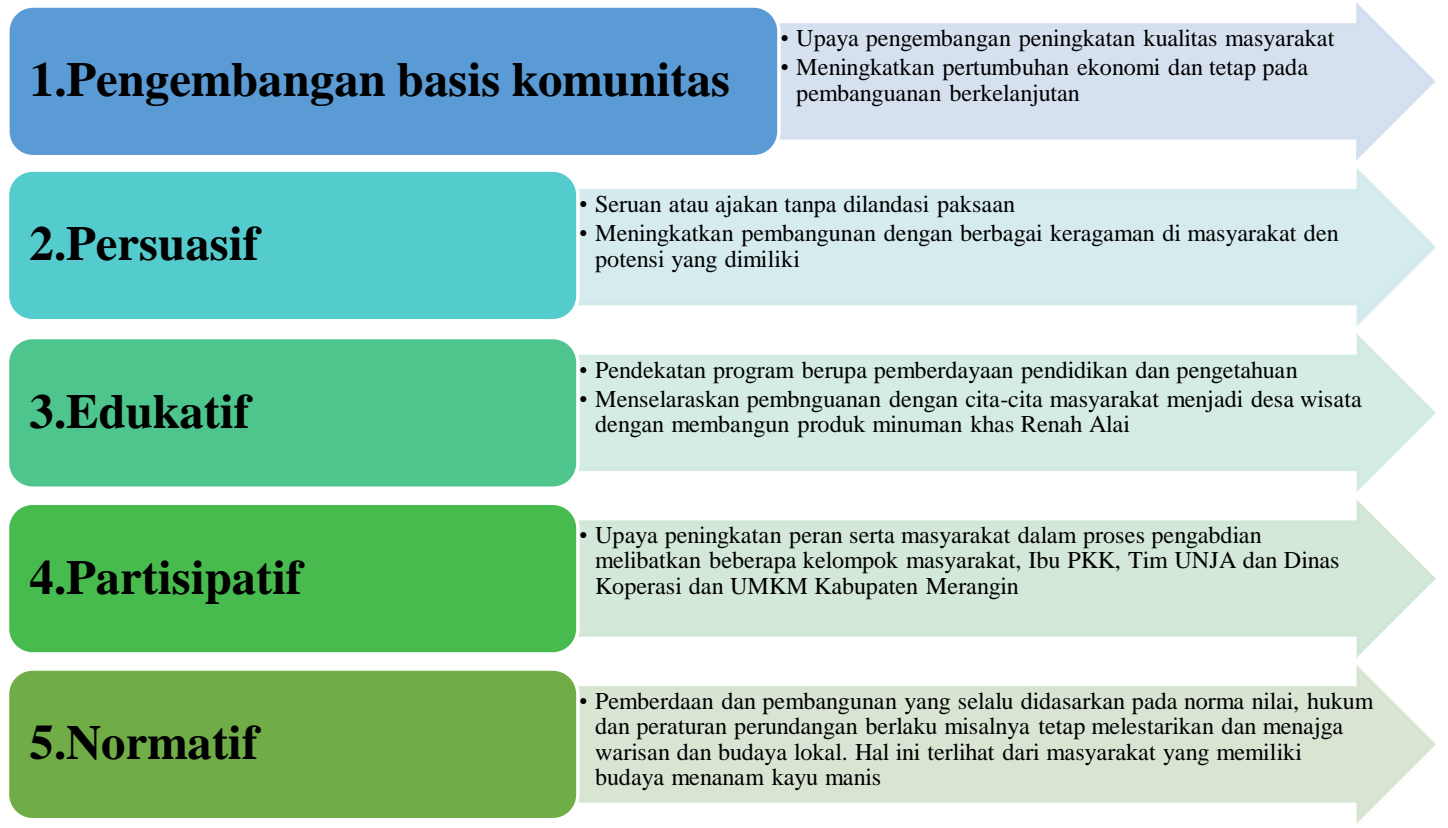

Gambar 3. Metode Pelaksanaan Pengabdian

Selain itu, dalam pelaksanaan pengabdian ini juga terkait dengan partisipasi mitra. Desa Renah Alai sebagai desa mitra menyediakan lokasi pengabdian, serta berkerjasama dalam menyampaikan potensi-potensi desa yang akan dijadikan sebagai Desa Renah Alai di Kecamatan Jangkat Kabupaten Merangin menjadi Desa wisata.

Pada tahap evaluasi pengabdian dilakukan dengan melihat perkembangan dari program yang telah laksanakan. Jika mengalami kendala maka akan direvisi program pengabdian kepada masyarakat agar tepat sasaran, efektif dan dapat maksimal. Walaupun pengabdian telah selesai, akan tetapi pembinaan di Desa Renah Alai Kecamatan Jangkat, Kabupaten Merangin terus dilakukan pembinaan supaya masyarakat Desa Renah Alai tetap mendapatkan arahan dalam pengembangan menuju Desa Wisata.

\section{Hasil dan Pembahasan}

\section{Hasil}

Peningkatan kesejahteraan masyarakat petani ubi jalar putih di Desa Renah Alai menjadi fokus utama karena mayoritas masyarakat hanya mengolah ubi jalar menjadi ubi rebus yang daya tahan yang sangat singkat. Selain itu, sebagian masyarakat langsung menjual ubi tersebut ke daerah lain dengan harga yang cukup murah. Peningkatan nilai tambah ubi dapat dilakukan dengan mengolah ubi jalar, dan dalam hal ini kulit kayu manis menjadi sirup kayu manis dengan daya tahan yang cukup lama dan harga yang cukup tinggi.

\section{Hasil Pengabdian Kepada Masyarakat}

Dalam pola pembinaan masyarakat menjadi masyarakat yang sejahtera harus mampu mengelola hasil pertaniannya menjadi produk ahkir yang memiliki nilai tambah yang lebih tinggi. Selain itu, masyarakat juga diharapkan dapat meningkatkan potensi wisata yang ada dengan memasarkan produk hasil olahan khas daerahnya sebagai oleh-oleh bagi wisatawan baik local maupun wisatawan luar yang berkunjung. Berkembangnya agro wisata di satu desa, tidak mempengaruhi pola kehidupan mereka baik dari sisi sosial, ekonomi dan budaya (Junaidi, dkk., 2019) 
Adapun cara pembinaan dapat dilakukan secara bertahap, yakni dilakukan sebelum daerah menjadi peningkatan usaha mikro dan kemudian suatu saat menjadi pusat oleh-oleh. Pembinaan ini dapat berupa pengarahan kepada setiap anggota masyarakat agar mempunyai persepsi yang sama dalam menghadapi berbagai permasalahan ketika wilayahnya akan dijadikan daerah agrowisata. Apabila masyarakat mempunyai persepsi yang sama, maka mereka akan memberikan sikap dan tingkah laku yang mendukung peningkatan usaha.

\section{Luaran yang Dicapai}

Berdasarkan solusi yang dijelaskan di atas, adapun target luarannya sebagai berikut::

1. Masyarakat semakin menyadari pentingnya pengelolaan hasil pertanian dalam meningkatkan nilai tambah produk dan akhirnya turut meningkatkan pendapatan masyarakat.

2. Meningkatkan permintaan ubi jalar putih sehingga harga kayu manis stabil dan cenderung meningkat. Hal ini juga akan menguntungkan bagi petani di Kecamatan Jangkat.

3. Meningkatkan kreativitas masyarakat dalam pengolahan kayu manis menjadi sirup kayu manis dapat meningkatkan kontribusi pariwisata dari segi oleh-oleh khas Desa Renah Alai sebagai produk asli masyarakat.

Setelah dilakukan pengabdian tahun sebelumnya oleh Prodi EP FEB UNJA dan melihat bahwa Desa Renah Alai memiliki banyak potensi yang dapat dikembangkan, maka pada tanggal 5 Juni 2020 Universitas Jambi mengadakan MoU Kerjasama yang diharapkan KKN mahasiswa dan pihak akademisi dapat mengembangkan Jangkat sebagai wilayah pengembangan pariwisata dan usaha lainnya.

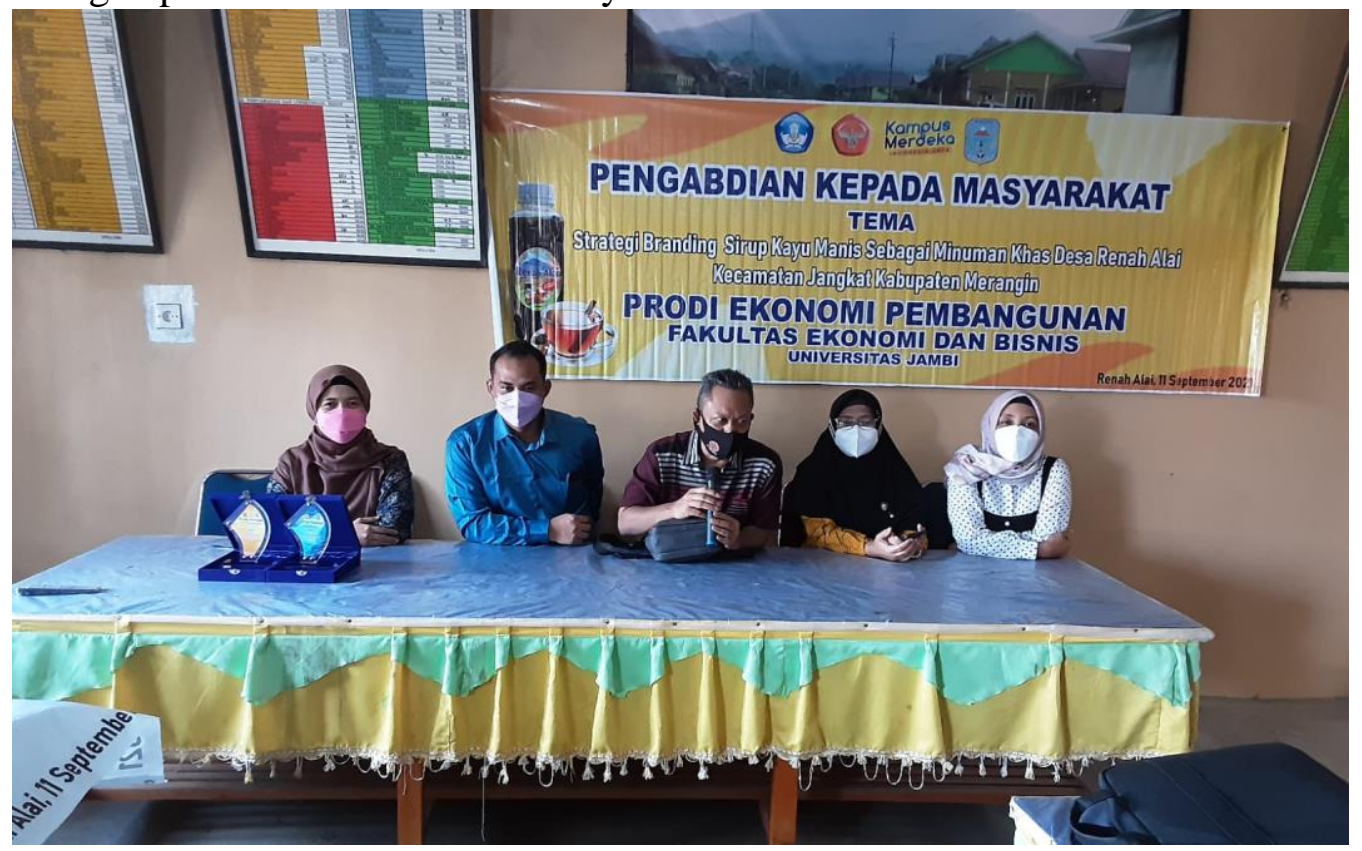

Gambar 4. Proses Pemaparan 


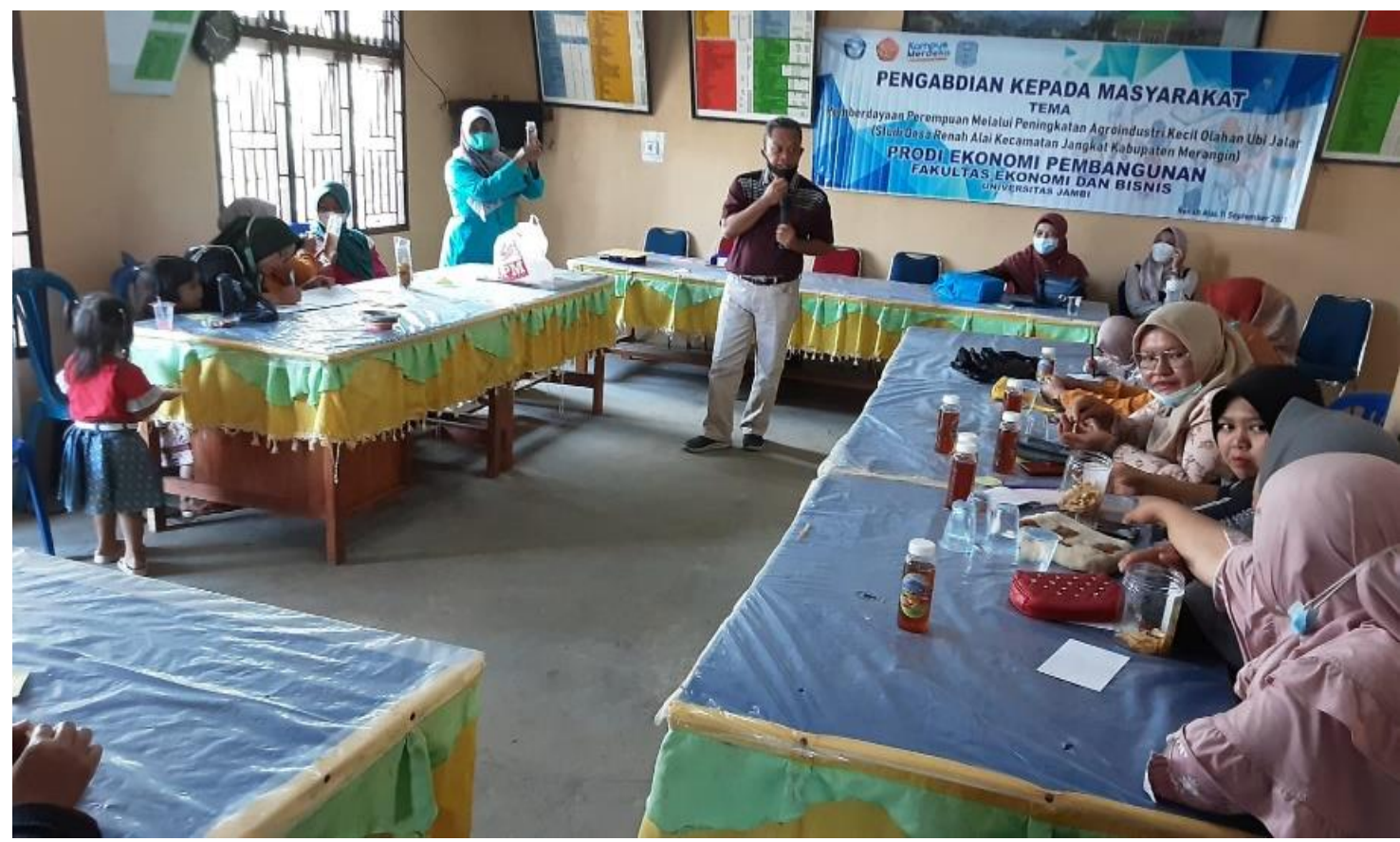

Gambar 5. Penyampaian Terkait Branding Produk Kayu Manis

\section{Kesimpulan dan Saran}

\section{Kesimpulan}

Berdasarkan pengabdian yang telah dilakukan, maka dapat disimpulkan sebagai berikut:

1. Kawasan Desa Renah Alai yang berada di Kecamatan Jangkat Kabupaten Merangin merupakan desa memiliki potensi dalam pengembangan kayu manis melalui diversifikasi olahan makanan menjadi sirup kayu manis dalam peningkatan nilai tambah dari sirup kayu manis yang kemudian dapat meningkatkan pendapatan petani.

2. Kegiatan pengabdian memberikan gambaran terkait dengan pemanfaatan kayu manis yang tidak hanya dijual mentah saja tetapi juga dapat dijadikan sirup kayu manis untuk mendapatkan keuntungan yang lebih besar bagi petani dan masyarakat di Desa Renah Alai.

3. Sirup kayu manis diharapkan dapat menjadi oleh-oleh khas dari Desa Renah Alai untuk wisatawan yang berkunjung dan singgah ke Danau Pauh dan wisata lainnya di wilayah Jangkat.

4. Selain untuk dijual, sirup kayu manis juga dapat sebagai pengganti sirup lain yang harganya jauh lebih mahal.

5. Untuk keberlanjutan program pengabdian pada masyarakat program studi ekonomi pembangunan Fakultas Ekonomi Universitas Jambi dengan memberdayakan mahasiswa dapat KKN di Desa Renah Alai yang telah menjadi Desa Mitra.

\section{Saran}

Adapun saran dari kegiatan pengabdian ini adalah sebagai berikut:

1. Perlunya bimbingan dari Dinas Perindustrian dan Perdagangan terkait pengembangan usaha sirup kayu manis supaya memiliki pangsa pasar yang potensial dalam pengembangan kreativitas dalam hal ini masyarakat di Desa Renah Alai. 
2. Perlunya kerjasama dari Dinas Pariwisata sehingga dapat bersinergi dalam mempromosikan hasil olahan usaha kulit kayu manis menjadi sirup kayu manis masyarakat Renah Alai selain dari potensi pertanian dan pariwisatanya.

3. Untuk keberlanjutan program pengabdian pada masyarakat program studi ekonomi pembangunan Fakultas Ekonomi Universitas Jambi yang telah dilakukan kerjasama sebagai salah satu desa binaan atau dampingan dari Fakultas Ekonomi Universitas Jambi, sehingga kedepannya diperkuat dengan peningkatan mutu hasil olahan dalam meningkatkan pangsa pasar.

\section{Daftar Pustaka}

Hendrayani, Y. and Manihuruk, H. (2020) 'Redesain kemasan dalam meningkatkan brand awarness produk unggulan UKM Cilodong Berkarya', Jurnal Bakti Masyarakat Indonesia. doi: 10.24912/jbmi.v3i1.8338.

Herydiansyah, G. (1970) 'Penyuluhan pentingnya label pada kemasan produk dan pajak pada usaha kecil menengah (UKM) Desa Tebedak II Kecamatan Payaraman Ogan Ilir', Jurnal Ilmiah Pengabdian Kepada Masyarakat.

Kastaman, R. and Thoriq, A. (2021) 'Prioritas strategi pengembangan agroindustri Manggis di Kabupaten Tasikmalaya, Jawa Barat', Agrikultura. doi: 10.24198/agrikultura.v31i3.30525.

Kristianto, A. (2020) 'Pendampingan dan pelatihan pengelolaan limbah organik menjadi produk bernilai ekonomi di SMA Negeri 1 Bengkayang', Jurnal Abdimas BSI: Jurnal Pengabdian Kepada Masyarakat. doi: 10.31294/jabdimas.v3i2.8093.

Kurniawan, A. R. (2020) 'Tantangan pengembangan pariwisata berbasis masyarakat pada era digital di Indonesia (Studi Kasus Pengembangan Pariwisata Berbasis Masyarakat di Pangalengan)', Tornare, 2(2), pp. 1-10. doi: 10.24198/tornare. v2i2.25418.

Mertayasa, D. M. and Yambese, A. R. (2017) 'Sistem informasi pariwisata pantai berbasis web', Elektronik Sistem Informasi dan Komputer.

Nurmiyati, Muzzazinah and Saputra, A. (2019) 'Pemanfaatan perca menjadi barang bernilai jual di Dusun Lemahireng, Desa Kaligawe, Klaten', Jurnal Abdimas.

Parmadi, Dwi Hastuti, Erfit, Rahma Nurjanah, F. Z. (2019) 'Pengolahan limbah organik rumah tangga di Desa Renah Alai Kabupaten Merangin', Jitdm), 1(1), pp. 43-50. Available at: https://www.online-journal.unja.ac.id/JITDM/article/view /8677.

Rai Utama, I. G. B. and University, D. P. (2012) Agrowisata sebagai pariwisata alternatif di Indonesia: Solusi Masif Pengentasan Kemiskinan. Available at: http://tourismbali.wordpress.com/.

Rusdi, J. F. (2019) 'Peran teknologi pada pariwisata Indonesia', Jurnal Accounting Information System (AIMS), 2(2), pp. 78-118. doi: 10.32627/aims.v2i2.78.

Sholawati, L. D. et al. (2020) 'Upaya meningkatkan nilai ekonomi pelaku umkm melalui digital marketing di tengah pandemi Covid-19 Dusun Karanganyar', Abdipraja (Jurnal Pengabdian kepada Masyarakat). doi: 10.31002/abdipraja.v1i1.3206.

Siswanto, V. A. (2009) 'Studi peran perempuan dalam pengembangan Kota Pekalongan ( Penelitian ini dibiayai oleh Kementrian Negara Pemberdayaan Perempuan )', Dinamika Informatika.

Susanto, A. and Nurcahyanto, B. (2018) 'Sosialisasi pentingnya branding dan menambah nilai ekonomis produk buah mangga di Desa Batok', Media Komunikasi dan Informasi Hasil Pengabdian dan Pemberdayaan Masyarakat. 
Yasa, N. N. K. et al. (2020) 'Strategi peningkatan internasionalisasi pada ukm kerajinan kayu di Kabupaten Gianyar', Buletin Studi Ekonomi. doi: 10.24843/bse.2020. v25.i01.p09.

Yudanto, A. A., Raharjo, T. and Ubed, R. S. (2019) 'Pendampingan pengembangan produk unggulan kawasan perdesaan pada usaha berbasis komunitas Desa Cibogo',

Dinamisia : Jurnal Pengabdian Kepada Masyarakat. doi:

10.31849/dinamisia.v2i2.2297. 